\title{
A tudatelmélet életkori változásainak és szerepének áttekintése óvodáskortól fiatal felnőttkorig
}

A tudatelmélet (Theory of Mind, ToM) gyermekkori tipikus fejlódése és atipikus mintázata számos pszichológiai, pszichiátriai és neurológiai kutatás témájául szolgál, mérésére sokféle eljárást használnak. A tudatelmélet képességének csecsemókori és óvodáskori fejlódési állomásainak leirása és empirikus vizsgálata sok kutatás alapja, azonban a tudatelmélet iskoláskori, serdülókori fejlódésére vonatkozó adatok kevéssé lelhetók fel a szakirodalomban. Jelen tanulmányban a tudatelmélet kisgyermekkori, serdülókori fejlódését tekintjük át, továbbá kitérünk a tudatelmélet és a szociális készségek kapcsolatának vizsgálatára, illetve az iskolai alkalmazkodásban való jelentóségére.

\section{A tudatelmélet (Theory of Mind) fogalma és komponensei}

A tudatelmélet fogalmát Premack és Woodruff (1978) vezette be, feltételezve, hogy a csimpánzok képesek saját fajtársuk mentális állapotaira következtetni. A fejlödéslélektan elsősorban a tudatelmélet ontogenetikus fejlödését, a pszichopatológia pedig a különböző fejlődési, pszichiátriai zavarokban jelentkező tudatelméleti deficiteket vizsgálja (Brüne és Brüne-Cohrs, 2006). A tudatelmélet olyan általános társas-kognitív képességünk, melynek segítségével önmagunknak és másoknak elmemüködést feltételezünk, azaz mentális állapotokat tulajdonítunk (pl. vágyakat, szándékokat, gondolatokat, érzéseket). A tudatelméleti képesség folyamatosan fejlődik, majd felnőttkorra alakul ki és ekkor müködik a legkifinomultabban (Baron-Cohen, 2001; Kiss, 2005; Bíró, 2002; Egyed és Király, 2008).

A ToM fogalma többféleképpen jelenik meg a magyar és az angol szakirodalomban: a mentalizáció, az elmeolvasás, az elmeteória, a naiv pszichológia elnevezések szerepelnek a témával foglalkozó kutatásokban. A tudatelmélet kifejezést számos kutatásban tág értelemben használják, vagyis minden olyan kognitív kompetenciát értenek alatta, melyek a társas életben való eligazodást segítik (Csibra és Gergely, 2002). A fogalom eredeti, szük definiálását Csibra és Gergely $(2002,56$. o.) fogalmazták meg, ennek alapján a tudatelmélet ,az a mechanizmus, amellyel másoknak (és néha magunknak) reprezentációs jellegü, a valós, vagy egy lehetséges világot leképező mentális állapotokat, tehát vélekedéseket, tudást, vágyakat, szándékokat tulajdonítunk, és nem foglalkozunk azokkal a készségekkel (empátia, utánzás, érzelmi állapotok észlelése, kommunikáció stb.), amelyek nem, vagy nem feltétlenül járnak együtt mentális attribúcióval". A tudatelmélet képessége a társas alkalmazkodáshoz elengedhetetlenül fontos, ennek birtokában képesek vagyunk a velünk interakcióba lépő egyének viselkedését elöre jelezni, magyarázni, 
értelmezni, továbbá segíti kommunikációnkat, szerepe van a kooperációban, a viselkedés irányításában és befolyásolásában, interakció kezdeményezésében és fenntartásában (Kiss, 2005). A tudatelméleti képesség müködése nélkül a szociális alkalmazkodásunk jóval nehezebbé válna.

A ToM differenciáltabb leírására többféle megkülönböztetés született. Nem egységes fogalomként definiálható, egyes kutatók szerint különbség van a tudatelmélet két komponense között: az affektív és a kognitív ToM komponenseit definiálják (Shamay-Tsoory és $m t s a i, 2007)$. Kognitív tudatelmélet alatt azt értjük, amikor az egyén racionálisan reagál más emberek mentális állapotaira, vagyis gondolkodik mások vélekedéseiről. Az affektív tudatelmélet azt jelenti, hogy más emberek érzéseiről vélekedünk (Kalbe és mtsai, 2010; Bodden és mtsai, 2010; Poletti és mtsai, 2011). Az affektív tudatelmélet és az empátia fogalmainak integrálását Shamay-Tsoory és munkatársai (2010) alakították ki modelljükben. Az empátia szintén kognitív és affektív komponensre bontható, ezekhez a komponensekhez kapcsolódva rajzolódik ki az affektív és a kognitív tudatelmélet müködése az empátia kapcsán. A kognitív empátiához kapcsolódik az affektív tudatelmélet, mivel az affektív ToM magában foglalja az empátia kognitív aspektusait. Az affektív tudatelmélet emellett bizonyos mértékig köthető az érzelmi/affektív empátiához is, hiszen interakcióban állnak egymással. A kognitív tudatelmélet az affektív tudatelmélet elöfeltétele a modellben. A kognitív és affektív empátia, illetve tudatelmélet közötti különbségtételt elsősorban az érzelmek központi szerepe jelöli ki. Az empátia összetevőjének tekinthető az érzelmi fertőzés, ami támogatja azt a képességünket, hogy átélhessük mások érzelmeit, érzelmi állapotait (Shamay-Tsoory és mtsai, 2010). Az empátia és a tudatelmélet komponensei az ismertetett modellben az 1. ábrán szemléltetett módon kapcsolódnak össze.

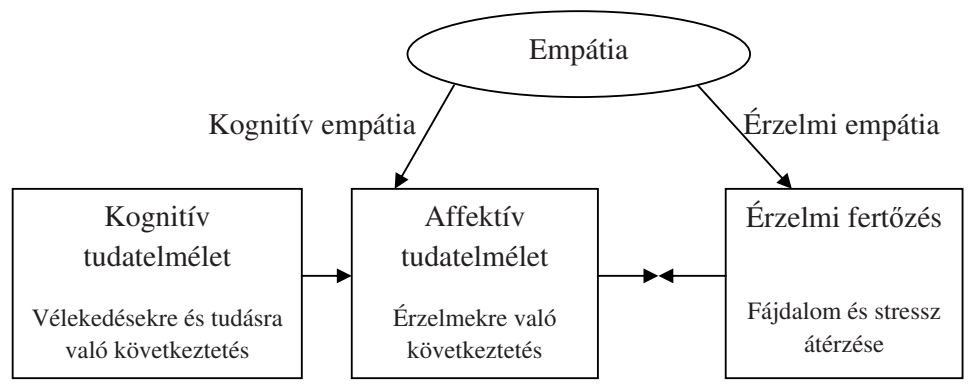

1. ábra. A kognitiv és affektiv tudatelmélet és az empátia összetevőinek kapcsolata Shamay-Tsoory és munkatársai (2010, 669. o.) nyomán

Apperly (2011) modelljében két elkülönülő rendszert feltételez felnőttek esetében az elmeolvasáshoz szükséges kognitív folyamatok feldolgozása alapján. A modell vertikális és horizontális dimenziókat tartalmaz. A vertikális dimenzióban elkülöníti az alacsonyabb és a magasabb szintü folyamatokat, a horizontális dimenzió az elmeolvasás potenciális folyamatait különíti el. A vertikális dimenzióban az egyik rendszer alacsonyabb szintü, gyors, automatikus, de kevésbé rugalmas információfeldolgozást tesz lehetővé, kevésbé veszi igénybe az általános kognitív funkciókat, nem vagy kevésbé tudatos (implicit, automatikus). A másik rendszer magasabb szintü, környezetfüggő és rugalmas, azonban nagymértékü kognitív terheléssel jár, jelentősen igénybe veszi a figyelmi, az emlékezeti és a végrehajtó funkciókat. Az elmeolvasási/tudatelméleti képességeknek tehát egyszerre kellően rugalmasnak kell lenniük ahhoz, hogy lehetővé váljon a komplex mentális állapotok megértése, az ezekről való gondolkodás, illetve kellően gyorsnak és hatékonynak kell lennie annak érdekében, hogy eligazodhassunk a társas interakciókban. 
A horizontális dimenzióban igyekeztek elválasztani a tudatelméleti működés lehetséges alfolyamatait, a szerző szerint hasznos lehet elkülöníteni az elmeolvasásban részt vevő kognitív folyamatokat csakúgy, mint a mentális állapotokkal kapcsolatos következtetéseket, az információk tárolását, illetve felhasználását más folyamatok számára (Apperly, 2011).

Az ismertetett modellek feltételezik, hogy a tudatelméleti müködés nem egységes rendszer, hanem különböző komponensek és folyamatok játszanak szerepet a megfelelö tudatelméleti funkcionálásban. Ezen modellek mellett más megközelítések is tárgyalják a tudatelmélet nem egységes rendszerét (pl. Allen, Fonagy és Bateman, 2011; Tine és Lucariello, 2012; Dennis és mtsai, 2013). A mérőeljárások és a fejlődési adatok vonatkozásában a továbbiakban az affektív-kognitív komponensekre fókuszálunk.

\section{A tudatelmélet mérőeljárásai}

A tudatelméletet mérő eljárások igen változatosak, egyes mérőeszközök különböző fejlettségi szintet kívánnak meg a vizsgálati személytől, így például életkortól vagy zavartól függően alkalmazhatók (Baron-Cohen, 2001). A tudatelmélet zavarainak vizsgálatában mind a kognitív, mind az affektív tudatelméleti komponenst mérő eljárásokat, mind a komplex tudatelméleti teszteket alkalmazzák. Az alábbiakban a leggyakrabban használt eljárásokat ismertetjük.

A tudatelmélet gyermekkori fejlődésében körülbelül négyéves korban a gyermekek megértik a hamis vagy téves vélekedéseket. Az igaz vélekedés a valóság aktuális állapotán alapszik, azonban a téves vélekedés csak a másiknak a világ állapotáról alkotott mentális reprezentációja alapján érthető meg. A hamis vélekedés vizsgálatára kialakított módszerek közül a „váratlan áthelyezés” (Maxi csokija, Sally-Anne teszt) és a „váratlan tartalom" (Smarties doboz) a leginkább alkalmazott (Bíró, 2002). A váratlan áthelyezés feladatban (Wimmer és Perner, 1983) a szereplő távollétében áthelyez a vizsgálatvezető egy tárgyat egy új helyre, a visszajövő szereplő mentális állapotának a megértése a feladat. A váratlan tartalom feladatban (Hogrefe, Wimmer és Perner, 1986) egy ismert dobozban a várttól eltérő tartalom van (pl. cukorkás dobozban ceruzák), egy nem jelenlévő személynek a doboz tartalmáról alkotott reprezentációjára kíváncsi a feladat (Bíró, 2002). Ezek az eljárások elsőfokú hamisvélekedés-megértést kívánnak meg a vizsgálati személytől. Ám a másodfokú hamis vélekedés megértése fejlettebb képességet kíván meg. Ekkor a beágyazott mentális állapotokat kell megérteni a vizsgálatban részt vevőnek, vagyis egy személy gondolatainak/vélekedéseinek kikövetkeztetése történik egy másik személy gondolatairól/vélekedéseiről, ami egy 6-7 éves gyermek gondolkodásának felel meg (Baron-Cohen, 1995). Az első- és másodfokú hamis vélekedést mérö eljárások a tudatelmélet kognitív komponensének mérésére alkalmazhatók (Poletti és mtsai, 2011).

A magasabb rendű, affektív tudatelméleti komponenst mérő eljárás a Reading the Mind in the Eyes Test (Baron-Cohen, Jolliffe, Mortimore és Robertson, 1997; Baron-Cohen, Weelwright, Hill, Raste és Plumb, 2001; Poletti és mtsai, 2011), magyar változatát Szemekből Olvasás Teszt néven Ivády, Takács és Pléh (2007) alakították ki. A tesztben a vizsgálati személy számára képeket mutatunk emberi arcok szempárjairól, majd azt kérjük, hogy ítélje meg, melyik szó írja le legjobban azt, amit a képen látható személy érez vagy gondol.

Számos klinikai, a tudatelmélet zavarait vizsgáló kutatásban alkalmazzák a Faux Pas Felismerése Tesztet (Stone, Baron-Cohen és Knight, 1998; Baron-Cohen, O'Riordan, Stone, Jones és Plaisted, 1999; magyar vizsgálatban pl. Gál, Egyed, Pászthy és Németh, 2011). A tesztben rövid történetek szerepelnek, melyekben egy társas helyzetben történő 
elszólás ('faux pas') felismerése a cél. A faux pas megértésekor a vizsgálati személynek fel kell ismernie, hogy az elszólás véletlenül történt, valamint azt is, hogy az elszólás megbánthatott egy másik személyt (Stone, Baron-Cohen és Knight, 1998; Baron-Cohen és mtsai, 1999). A teszt a kognitív és az affektív mentális állapotok vizsgálatára is alkalmas (Poletti és mtsai, 2011). A faux pas felismerése 9-11 éves korban alakul ki (Baron-Cohen és mtsai, 1999).

Ezen vizsgálati módszereken túl számos további mérőeljárás alkalmas a tudatelméleti teljesítmény mérésére ( $\mathrm{pl}$. Yoni teszt a komplex ToM mérésére), illetve igen sok kutatás saját fejlesztésü mérőeszközökkel dolgozik. Ugyanakkor sok esetben az ismertetett eljárások adják az alapot az újabb eszközök kidolgozásához.

\section{A tudatelmélet életkori változásai}

A tudatelmélet képességének fejlődésében különböző állomások írhatók le. Maga a képesség felnőttkorra alakul ki és éri el azt a szintet, ahol már egészen kifinomultan müködik. A tudatelméleti képesség fejlődésének tanulmányozása során kutatások arra mutattak rá, hogy a csecsemők viselkedésében is megjelennek olyan mintázatok, amelyek a tudatelmélet elöfutárainak tekinthetők (pl. Bíró, 2002; Csibra, Bíró, Koós és Gergely, 2003; Csibra és Gergely, 2002; Csibra és Gergely, 2005; Gergely, Egyed és Király, 2007; Kovács, Téglás és Endress, 2010).

A tudatelmélet kisgyermekkori, majd iskoláskori és serdülőkori fejlődésében elsősorban az egyes életkorokban megjelenő, az adott életkori övezethez köthető sajátosságokat ismertetjük, bemutatva a tudatelméleti müködés egyre összetettebbé válását. Jelen tanulmányban nem térünk ki a nemi különbségekre, illetve a nyelvi és az általános kognitív funkciókkal való kapcsolatára. A kisgyermekkori fejlődés tanulmányozásában a hamis vélekedés megértésének kutatása nagy érdeklődésre tart számot. Az eredmények arra utalnak, hogy a 3-4 éves korú gyermekek képesek megérteni a hamis vélekedést, vagyis azt, hogy egy személynek a valóságtól eltérő gondolatai vannak a világról. Majd hatéves kor körül a gyermekek megértik egy személy gondolatait egy másik személy gondolatairól, vagyis képesek megérteni a beágyazott mentális állapotokat. Körülbelül nyolcéves korban a gyermekek képesek megérteni metaforát és iróniát, ez pedig azt a képességet kívánja meg a személytől, hogy megértse egy kijelentés nem szó szerinti jelentését, továbbá képesek elkülöníteni a viccet a hazugságtól (Brüne és Brüne-Cohrs, 2006; Bíró, 2002, Kiss, 2005; Baron-Cohen, 2001). Később, a tudatelmélet képességének fejlődésével a 9-11 éves gyerekek megértik a faux pas-t, vagyis egy olyan, társas helyzetben véletlenül történt elszólást, ami rossz érzést kelthetett másokban. A faux pas megértése már egy fejlettebb tudatelméletet igényel, hiszen két mentális állapot egyidejü megértését követeli meg: a faux pas-t elkövető személy perspektíváját, aki nincs tudatában elszólásának, illetve a másik személy perspektíváját, akit megbántott, megbánthatott az elszólás (Baron-Cohen, O'Riordan, Stone, Jones és Plaisted, 1999). Annak ellenére, hogy nagyon sok eredmény szól a gyermekkori tudatelméleti müködés feltérképezéséröl, kevés adatunk van arra vonatkozóan, hogyan alakul, változik, módosul (és minek hatására) ez a képesség akár serdülőkorban, akár később, egészséges felnőttek körében. Feltételezhető, hogy a mentalizációs képesség folyamatos komplexebbé válásával számolhatunk a felnőttkori fejlődés folyamán (Brüne és Brüne-Cohrs, 2006).

A tudatelmélet kisgyermekkort követő fejlődésének tanulmányozása elsősorban idegtudományi kutatási eredményekhez köthetö, hiszen azon agyi területek, melyek a mentalizációs hálózathoz tartoznak, mind strukturális, mind funkcionális változásokon keresztülmennek még a serdülőkor folyamán (Blakemore, 2008, 2012). Dumontheil, Apperly és Blakemore (2010) öt korcsoportban - (1) 8,9 év; (2) 10,6 év; (3) 12,7 év; (4) 
15,3 év; (5) 22,8 év - végzett vizsgálatai szerint a tudatelméleti müködés fejlődése még a késő serdülőkor és a felnőttkor között is megfigyelhető. Vagyis késő serdülőkorban is megfigyelhető a teljesítményjavulás mások perspektívájának megértésének képességében, azok után is, hogy a feladathoz szükséges munkamemória-kapacitás és gátlókontroll elérte a felnőttekre jellemző színvonalat. Javaslatuk szerint a kimutatott fejlődési mintázat a végrehajtó funkciók és a tudatelmélet közötti kölcsönhatásának folyamatos érését is jelzi (Dumontheil, Apperly és Blakemore, 2010).

Gunther Moor és munkatársai (2011) az affektív tudatelmélet fejlődését (Szemekből Olvasás Teszt) és ehhez kapcsolódó agyi aktivitását (fMRI) vizsgálták három korcsoportban (korai serdülö: 10-12 év; serdülő: 14-16 év; fiatal felnőtt: 19-23 év). Viselkedéses eredményeik szerint a legfiatalabb korcsoport is jóval a véletlen szintje fölött teljesített (legalább 60 százalékos pontossággal), azaz a szemekről történő érzelmek leolvasása, az affektív tudatelmélet már ebben a korai életkorban kialakul. Eredményeik a serdülők enyhe hanyatlását jelezték a 10-12 évesekhez és a fiatal felnőttekhez képest (Gunther Moor és mtsai, 2011).

A kognitív tudatelmélet fejlödése megelőzi az affektív tudatelmélet fejlödését, vagyis amíg a gyerekek 6-7 éves korban képesek megérteni a másodfokú hamisvélekedés-tulajdonítást, vagyis megértik, hogy A személy megérti B személy vélekedését, addig annak megértése, hogy A személy megérti B érzéseit, például a faux pas elkövetése kapcsán csak később, 9-11 éves kor között alakul ki (Sebastian és mtsai, 2012). Sebastian és munkatársai (2012) ezt viselkedéses (rajzolt figurákkal ábrázolt történetek, melyekben affektív, kognitív és fizikai oksági feltételt hoztak létre), illetve fMRI-adatokkal ellenörizték serdülők és felnőttek összehasonlításával. A viselkedéses adatok alapján az affektív tudatelméleti feladatokon a serdülők több hibát vétettek, mint a felnőttek, holott ez az életkori különbség a kognitív tudatelméleti feladatokban és a fizikai, azaz mentális állapottulajdonítást nem igénylő, kontrollfeladatokban nem volt szignifikáns. Mindez arra utal, hogy az affektív tudatelmélet fejlödést mutat a serdülőkor és a felnőttkor közötti időszakban (Sebastian és mtsai, 2012).

Az affektív tudatelmélet kapcsán fontos fejlődéslélektani eredmény, hogy a meglepetés érzelmének megértése már 7-9 éves korban kezd fejlődni, míg a komplex érzelmek, például a faux pas érzelmi következményeinek megértése később, 9-11 éves korban jelenik meg (Ruffman és Keenan, 1996, idézi Vetter és mtsai, 2013). Vetter és munkatársai (2013) kutatásukban életszerü tudatelméleti feladatokkal (Cambridge Mindreading Face-Voice Battery faces skálája) vizsgálták az affektív tudatelméleti komponens serdülö- és fiatal felnőttkori fejlődését a végrehajtó funkciókkal összefüggésben. Az adatok alapján az életkor és az affektív tudatelméleti teljesítmény erős összefüggésben áll még a végrehajtó funkciók és az általános kognitív képességek kontrollálását követően is. Továbbá az eredmények azt mutatják, hogy az affektív tudatelméleti komponens és a végrehajtó funkciók közül a gátlás, a váltás és a frissítés képessége között szoros összefüggés áll fenn, a három végrehajtó funkció jó előrejelzője a tudatelméleti teljesítménynek, különösen igaz ez a gátlás funkciójának esetében (Vetter és mtsai, 2013).

Altgassen és munkatársai (2014) serdülöket és fiatal felnőtteket hasonlítottak össze tudatelméleti, végrehajtó funkciót és prospektív emlékezetet mérő feladatokon nyújtott teljesítményük alapján. Eredményeik szerint serdülőkorban a tudatelméleti működés és a váltás képessége bejósolja a prospektív emlékezeti múködést, ugyanakkor ez a hatás már a fiatal felnőttek esetében nem figyelhető meg. A tudatelméleti müködés egészen fiatal felnőttkorig fejlődik, változik a tipikus fejlődésben. A serdülőkori affektív és kognitív tudatelméleti fejlődés adatait az 1. táblázatban ismertetjük. 


\begin{tabular}{|c|c|c|c|c|}
\hline \multicolumn{5}{|c|}{ 1. táblázat. A tudatelmélet és komponenseinek fejlödése kisiskoláskortól serdülökorig } \\
\hline Szerzök & Vizsgált korosztály & $\begin{array}{c}\text { ToM mérésére } \\
\text { szolgáló eljárások }\end{array}$ & $\begin{array}{c}\text { Mért ToM- } \\
\text { komponensek }\end{array}$ & Főbb eredmények \\
\hline $\begin{array}{l}\text { Dumontheil, } \\
\text { Apperly és } \\
\text { Blakemore } \\
(2010)\end{array}$ & $\begin{array}{l}\text { Gyermek I: } 8,9 \text { év } \\
\text { Gyermek II: } 10,6 \text { év } \\
\text { Serdülö I: } 12,7 \text { év } \\
\text { Serdülö II: } 15,3 \text { év } \\
\text { Felnőtt: } 22,8 \text { év }\end{array}$ & $\begin{array}{l}\text { Referenciális } \\
\text { kommunikációs } \\
\text { feladat (Keysar } \\
\text { és mtsai, } 2000 \\
\text { alapján) }\end{array}$ & & $\begin{array}{l}\text { Késő serdülőkorban is } \\
\text { megfigyelhető a tel- } \\
\text { jesítményjavulás más } \\
\text { személyek perspektívája } \\
\text { megértésének képessé- } \\
\text { gében. }\end{array}$ \\
\hline $\begin{array}{l}\text { Gunther Moor } \\
\text { és munkatársai } \\
(2011)\end{array}$ & $\begin{array}{l}\text { Korai serdülő: } 10-12 \text { év } \\
\text { Serdülő: } 14-16 \text { év } \\
\text { Fiatal felnőtt: } 19-23 \text { év }\end{array}$ & $\begin{array}{l}\text { Szemekből Olva- } \\
\text { sás Teszt adaptált } \\
\text { változata }\end{array}$ & $\begin{array}{l}\text { Affektív tudat- } \\
\text { elméleti kompo- } \\
\text { nens. }\end{array}$ & $\begin{array}{l}\text { Az érzelmek és gondo- } \\
\text { latok szemek alapján } \\
\text { történő dekódolása már } \\
\text { korai életkorban meg- } \\
\text { jelenik. }\end{array}$ \\
\hline $\begin{array}{l}\text { Sebastian és } \\
\text { munkatársai } \\
(2012)\end{array}$ & $\begin{array}{l}\text { Serdülö: } 14,8 \text { év } \\
\text { Felnőtt: } 28,88 \text { év }\end{array}$ & $\begin{array}{l}\text { Rajzolt karakterek } \\
\text { által szemléltetett } \\
\text { történetek (Völlm, } \\
2006 \text { alapján) }\end{array}$ & $\begin{array}{l}\text { Affektív, kogni- } \\
\text { tív tudatelméleti } \\
\text { komponens és } \\
\text { kontroll feltétel. }\end{array}$ & $\begin{array}{l}\text { Az affektív tudatelmélet } \\
\text { még a serdülőkor és } \\
\text { a felnőttkor között is } \\
\text { fejlődést mutat. }\end{array}$ \\
\hline $\begin{array}{l}\text { Vetter és } \\
\text { munkatársai } \\
(2013)\end{array}$ & $\begin{array}{l}\text { Középiskolás/serdülö } \\
\text { Egyetemista/fiatal } \\
\text { felnött } \\
(12,08-22,92 \text { év) }\end{array}$ & $\begin{array}{l}\text { Cambridge } \\
\text { Mindreading } \\
\text { Face-Voice } \\
\text { Battery ,facial } \\
\text { skale” }\end{array}$ & $\begin{array}{l}\text { Affektív tudat- } \\
\text { elméleti kompo- } \\
\text { nens, végrehajtó } \\
\text { funkciók. }\end{array}$ & $\begin{array}{l}\text { Az életkor és az affektív } \\
\text { tudatelméleti teljesít- } \\
\text { mény között erös össze- } \\
\text { függés. } \\
\text { Az affektív tudatelméleti } \\
\text { komponens és a végre- } \\
\text { hajtó funkciók közül a } \\
\text { gátlás, a váltás és a fris- } \\
\text { sítés képessége között } \\
\text { szoros összefüggés. }\end{array}$ \\
\hline $\begin{array}{l}\text { Altgassen és } \\
\text { munkatársai } \\
(2014)\end{array}$ & $\begin{array}{l}\text { Serdülő: } 13,55 \text { év } \\
\text { Fiatal felnőtt: 19,44 év }\end{array}$ & $\begin{array}{l}\text { Story } \\
\text { Comprehension } \\
\text { Test }\end{array}$ & $\begin{array}{l}\text { Kognitív tu- } \\
\text { datelméleti } \\
\text { komponens, } \\
\text { végrehajtó funk- } \\
\text { ciók, prospektív } \\
\text { emlékezet. }\end{array}$ & $\begin{array}{l}\text { Fiatal felnőttek tudat- } \\
\text { elméleti teljesítménye } \\
\text { jobb, mint a serdülőké. } \\
\text { A váltás és a tudat- } \\
\text { elméleti müködés a } \\
\text { prospektív emlékezeti } \\
\text { teljesítményt előrejelzi } \\
\text { serdülökorban. }\end{array}$ \\
\hline
\end{tabular}

\section{A tudatelmélet fejlődésében szerepet játszó családi tényezők}

A tudatelmélet tipikus, normál ütemü fejlődését bizonyos tényezők kedvező irányban befolyásolják. A nyelvi készségek fejlettségi szintje is hatással van a tudatelméleti müködésre, vagyis azok a gyermekek, akik nyelvi készségei korán kialakultak, elősegítve a tudatelmélet fejlödését, későbbi hamisvélekedés-teszten magasabb teljesítményt értek el, azonban ez az összefüggés fordítva nem bizonyított (pl. Happé, 1995; Astington és Jenkins, 1999; Ruffmann, Slade és Crowe, 2002; Slade és Ruffmann, 2005). Mindemellett a tudatelmélet és a kognitív konstruktumok közötti kapcsolatra is rendelkezésünkre állnak adatok, például a tudatelméleti képesség és a végrehajtó funkciók (pl. Carlson és Moses, 2001; Carlson, Moses és Breton, 2002; Perner és Lang, 1999), a kreativitás (pl. Suddendorf és Fletcher-Flinn, 1999), illetve az erkölcsi gondolkodás ('moral reasoning', ld. pl. Dunn, Cutting és Demetriou, 2000) kapcsán. Fontos terület az egyéni változókon kívül azoknak a környezeti tényezöknek a vizsgálata is, amelyek szerepet játszanak a tudatelméleti képesség fejlődésében, ezek közül is elsősorban a családi tényezőkre fókuszálunk a továbbiakban. 
A családi tényezők közül elsősorban a családszerkezet, a gyermek testvéreinek száma, illetve a családon belüli kommunikációs mintázatok tudatelméleti teljesítményre gyakorolt hatásait kutatták. Dunn és munkatársai (1991) vizsgálatának eredményei szerint a tudatelmélet fejlődését nagymértékben elősegíti, ha a gyermekek anyjukkal és testvéreikkel játéktevékenység közben olyan társalgást folytatnak, melyben mentális állapotok (szándékok, vágyak, érzelmek) szerepelnek,. Továbbá kimutatták, hogy a családban az érzésekről való beszélgetések gyakorisága és a testvérekkel való együttmüködés a 33 hónapos gyermekek esetében kapcsolatban áll a 7 hónappal későbbi (40 hónaposan mért) hamisvélekedés-teszten nyújtott teljesítménnyel és az érzelmek megértésével (Cutting és Dunn, 1999).

A családi háttér, elsősorban a szocio-ökonómiai státusz (SES) hatása még kevéssé vizsgált terület a tudatelmélet szempontjából. Cutting és Dunn (1999) vizsgálatában óvodás gyermekek hamisvélekedés-teszten elért eredményeit, érzelemmegértését és családiháttér-változóikat hasonlították össze. A családiháttér-változók közül a családszerkezetet, a gyermekkel együtt élő felnőttek számát, a beszélt nyelvek számát, az egy családban élő gyermekek számát, illetve a szülők iskolai végzettségét és foglalkozását elemezték. A kutatás eredményei alapján a családiháttér-változók közül elsősorban a szülők foglalkozása és az anya iskolai végzettsége mutat kapcsolatot az óvodás gyermekek hamisvélekedés-teszten elért eredményeivel és az érzelmek megértésével. Pears és Moses (2003) vizsgálatukban elemezték a család demográfiai jellemzői és a tudatelmélet fejlettsége közötti kapcsolatot. Óvodáskorú gyermekek tudatelméleti fejlettségének legerősebb (ugyanakkor összességében mérsékelt összefüggést mutató) előrejelzője volt az anya iskolai végzettsége. A magyarázatok szerint az anyai iskolai végzettség direkt (a magasabb végzettségü anyák több időt töltenek a társas jelenségek magyarázatával) és indirekt (az általá-

Perner, Ruffmann és Leakam (1994) kimutatták, hogy azok a gyermekek, akiknek testvérük

van, jobban teljesitenek a hamisvélekedés-teszteken, mint az egyke gyerekek. Azok a 3-4 éves gyermekek, akiknek két vagy több testvére volt, jobb teljesitményt nyújtottak a teszteken, mint akiknek egy testvérük volt, illetve az egyke gyerekeknek megközelitoóen a fele tudta teljesíteni a tesztet ebben a kutatásban (Perner, Ruffmann és

Leakam, 1994). Jenkins és Astington (1996) ugyanezeket az eredményeket kapták, azonban azt is kimutatták, hogy a hamisvélekedés-teszten elért jobb teljesitményt nem befolyásolja, hogy a testvérek idósebbek vagy fiatalabbak, illetve a születési sorrendnek sincs szignifikáns hatása a teljesítményre. Eredményeik tehát azt támasztották alá, hogy minél nagyobb a család, minél több a testvérek száma, annál magasabb a gyermekek teszten elért teljesítménye (Jenkins és Astington, 1996). nos kognitív képességeken keresztül) úton is hatással lehet a gyermek tudatelméleti müködésére. A család anyagi helyzete pozitív kapcsolatban áll a gyermek teljesítményével: a család jövedelme feltehetően az anya magasabb iskolai végzettségén és a gyermekek kognitív képességein keresztül van hatással a tudatelméleti működésre. Ám a szülők családi állapotának nem volt jelentős 
magyarázóereje a tudatelméleti teljesítmény alakulására, vagyis a tudatelméleti funkcionálást nem magyarázta jelentős mértékben az, hogy a szülők egyedülállók, avagy házasságban, párkapcsolatban élnek (Pears és Moses, 2003).

A család mérete is meghatározó tényező a tudatelmélet fejlödésében, egyéni különbségeiben. Perner, Ruffmann és Leakam (1994) kimutatták, hogy azok a gyermekek, akiknek testvérük van, jobban teljesítenek a hamisvélekedés-teszteken, mint az egyke gyerekek. Azok a 3-4 éves gyermekek, akiknek két vagy több testvére volt, jobb teljesítményt nyújtottak a teszteken, mint akiknek egy testvérük volt, illetve az egyke gyerekeknek megközelítően a fele tudta teljesíteni a tesztet ebben a kutatásban (Perner, Ruffmann és Leakam, 1994). Jenkins és Astington (1996) ugyanezeket az eredményeket kapták, azonban azt is kimutatták, hogy a hamisvélekedés-teszten elért jobb teljesítményt nem befolyásolja, hogy a testvérek idősebbek vagy fiatalabbak, illetve a születési sorrendnek sincs szignifikáns hatása a teljesítményre. Eredményeik tehát azt támasztották alá, hogy minél nagyobb a család, minél több a testvérek száma, annál magasabb a gyermekek teszten elért teljesítménye (Jenkins és Astington, 1996).

Cutting és Dunn (1999) nem talált összefüggést a gyermekek testvéreinek száma és a tudatelméleti fejlettségük között. Javaslatuk szerint sokkal inkább a testvéri kapcsolat típusa és minősége van hatással a tudatelméleti fejlettségre, nem a testvérek száma (ld. még: Hughes és Ensor, 2005). Hasonlóan, Pears és Moses (2003) vizsgálatában nem volt kapcsolat a testvérek száma és a tudatelméleti működés között. McAllister és Peterson (2007) longitudinális vizsgálatukban arra az eredményre jutottak, hogy azok a gyermekek, akiknek két vagy több testvérük van, jobban teljesítenek a hamis vélekedés teszteken. Lewis, Freedman, Kyriakidou, Maridaki-Kassotaki és Berridge (1996) szerint az alábbiak vannak hatással a tudatelméleti teljesítményre: a felnőtt rokonok száma, akik a gyermek közvetlen környezetében élnek; a gyermek idősebb testvéreinek száma, illetve naponta a gyermekkel kapcsolatban álló idősebb gyermekek. McAllister és Peterson (2007) szerint a testvérek száma és a tudatelmélet fejlettsége közötti kapcsolat feltehetően abban keresendö, hogy a testvérek jelenléte a családban facilitálja a kortársak közötti kommunikációt és kapcsolatokat, és ezek vezethetnek a tudatelmélet gyors fejlődéséhez az óvodás korú (3-6 éves) gyermekek körében.

A szülői attitüd szintén befolyásolja a tudatelméleti funkcionálást, óvodások esetében az anya és a gyermek közötti mentális állapotokról való beszélgetések gyakorisága, kidolgozottsága és tudatelméleti fejlettsége (hamisvélekedés-teszten elért eredménye) szignifikáns összefüggésben állnak (Peterson és Slaughter, 2003). Hasonlóan, a hároméves kori, anyával történő, mentális állapotokkal kapcsolatos beszélgetések egyértelmü és erős kapcsolatban állnak a később mért tudatelméleti teljesítménnyel (Ruffman, Slade, Devitt és Crowe, 2006; Ruffman, Slade és Crowe, 2002). A szülői nevelési módszerek közül a hatalmat gyakorló fegyelmezési stílus, amelyben a szülők kiabálással, fizikai büntetéssel vagy direkt utasítással fegyelmezik a gyermekeiket, nem segít a tudatelméleti fejlődés előmozdításában. A hatalmat gyakorló fegyelmezési stílus és a vélekedések megértése között negatív kapcsolat áll fenn, még akkor is, ha a kognitív képességeket és a demográfiai hátteret kiszürték az elemzésböl (Pears és Moses, 2003).

A családiháttér-változók közül a testvérek és más felnőtt családtagok szerepe, továbbá demográfiai változók is fontos szerepet töltenek be a tudatelméleti fejlödésben. A tudatelmélet fejlődésének fontos háttere tehát a család szerkezete, müködése, azonban a társas alkalmazkodás, szükebben az iskolai társas kapcsolatok hatékony kezelése szempontjából fontos a tudatelmélet és a társas viselkedés közötti kapcsolatnak, vagy éppen a kapcsolat hiányának a vizsgálata. Vagyis az, hogy hogyan funkcionál például a jobb tudatelméleti müködéssel jellemezhető gyermek a társas világban, a kortársak között. Természetesen fontos szempont az is, hogy vajon a családiháttér-változók és az iskolai 
sikeres társas alkalmazkodás milyen viszonyban állnak egymással, mennyiben müködhet például a tudatelmélet közvetítő változóként ebben a relációban. Azonban a továbbiakban a tudatelméleti képesség és a társas viselkedés bizonyos aspektusai közötti kapcsolatokat ismertetem.

\section{A tudatelmélet kapcsolata a társas viselkedéssel}

A tudatelmélet - fogalma szerint - társas-kognitív képességnek tekinthető, a szociális alkalmazkodásunk egy kulcsképessége, fejlődésében is szerepet játszanak a szociális ingerek, interakciók. Fontos tehát annak kérdése, hogy a tudatelméleti müködés milyen kapcsolatban áll a szociális készségekkel, hiszen elengedhetetlen annak vizsgálata, hogy a laboratóriumban végzett tudatelméleti tesztek és a szociális készségek között kimutatható kapcsolat vajon a való életben is megjelenik-e (Baron-Cohen, 2001). Számos tanulmány született a tudatelmélet szociális viselkedéssel való összefüggésének vizsgálatára. A tudatelméleti kutatások kezdetben arra világítottak rá, hogy a mentalizációs képesség társas alkalmazkodásban betöltött szerepe elsősorban a tudatelméleti zavarok kapcsán érthető meg. Baron-Cohen, Leslie és Frith (1985) autizmussal élő gyerekek vizsgálata kapcsán feltételezte a tudatelmélet deficitjét, mely a szociális interakciókban történő zavarra ad magyarázatot autizmusban. Ezt a kezdeti kutatást számos további vizsgálat követte mind autizmusban (pl. Baron-Cohen, O’Riordan, Stone, Jones és Plaisted, 1999; Baron-Cohen, Weelwright, Hill, Raste és Plumb, 2001), mind más fejlődési zavarral, illetve pszichiátriai zavarral diagnosztizált csoportokban egyaránt. Az iskolai alkalmazkodás kapcsán azonban számunkra most a tipikusan fejlődő gyermekek szociális alkalmazkodásával kapcsolatos eredmények a legérdekesebbek.

\section{Tudatelmélet és társas viselkedés összefüggése óvodáskorban}

A kutatások eredményei arra utalnak, hogy a tudatelmélet képessége a szociálisan hatékony viselkedéssel (pl. Lalonde és Chandler, 1995) vagy a társas kapcsolatok minőségével együtt jár (Slaughter és Repacholi, 2003). Vagyis a magasabb szintü tudatelméleti működéssel rendelkező gyerekek sikeresebbek a társas kapcsolatokban. Azonban a magasabb szintü tudatelméleti müködés nem garantálja egyértelmüen a társas hatékonyságot, hiszen vannak olyan gyermekek és felnőttek, akik jó tudatelméleti képességüket antiszociális célokra használják (pl. bullying jelenségének vizsgálata) (Slaughter és Repacholi, 2003). Vagyis a tudatelméleti képesség és a társas viselkedésbeli következmények vizsgálata nagyon összetett terület, melyben sok ellentmondás fedezhető fel.

Az ellentmondások leginkább abból erednek, hogy a valós társas környezetben való alkalmazkodás, a társas interakciók kezelése és a laboratóriumban, mesterséges körülmények között felvett tudatelméleti tesztek eredményei között sok esetben nincs összhang. Ha egy gyermek például nem tud teljesíteni egy tudatelméleti tesztet, az még nem feltétlenül jelenti azt, hogy a társas helyzetekben ne tudna alkalmazkodni, vagy a másik személy perspektíváját átvenni, vágyait, érzelmeit megérteni. Vagyis annak ellenére például, hogy egy hároméves gyermek még nem teljesíti a hamisvélekedés-tesztet, sikeresen képes kezelni a társas helyzeteket (Astington, 2003).

A következőkben ismertetett vizsgálati eredmények a tudatelmélet és a társas viselkedés közötti pozitív összefüggésekre, illetve az összefüggések hiányára is utalnak. Newton, Reddy és Bull (2000) vizsgálatában a tudatelméleti teljesítmény és a mindennapi életben megfigyelt, a gyermekek édesanyja által regisztrált megtévesztések között nem találtak szignifikáns összefüggéseket 3-4 éves korú gyermekek körében. Ennek ellentmondó eredmény ugyanakkor, hogy hároméves gyermekek hamisvélekedés-teszten 
nyújtott teljesítménye és a pedagógus által megítélt társas viselkedése között összefüggést találtak (Lalonde és Chandler, 1995). Hasonlóan Watson és munkatársai (1999) 3 és 6 éves gyermekek hamisvélekedés-teszten elért eredményei és a pedagógus által megítélt szociális készségei között találtak összefüggéseket. A hamisvélekedés-teszten nyújtott teljesítmény szignifikáns előrejelzője volt a pedagógus által megítélt társas viselkedésüknek.

Nagyobb mintán, hasonló életkorú gyerekekkel végzett vizsgálataik szintén megerősítették a hamisvélekedés-teszten nyújtott teljesítmény és a társas viselkedés közötti összefüggéseket (Watson, Nixon, Wilson és Capage, 1999). Walker (2005) vizsgálatában 3-5 éves korú gyermekek hamisvélekedés-teszten nyújtott teljesítménye és a pedagógusok által megítélt társas viselkedése közötti összefüggéseket tárt fel. A pedagógusok által megítélt viselkedést három területen vizsgálta: a negatív vagy pozitív viselkedés játékhelyzetben (kooperatív játék, verbális vagy fizikai agresszió), más gyermekek játékához csatlakozás stratégiái, illetve konfliktusokban való részvétel, illetve azok megoldási stratégiái. A tanári értékelések alapján három faktorba sorolhatók a társas viselkedési minták: proszocialitás, agresszivitás vagy bomlasztó viselkedés, illetve visszahúzódó viselkedés (Walker, 2005). Az eredmények arra utalnak, hogy a tudatelmélet összefüggésben áll az agresszív vagy bomlasztó viselkedéssel a fiúk esetében, míg a lányok esetében a proszociális viselkedéssel mutat pozitív kapcsolatot, ugyanakkor negatív összefüggésben áll a visszahúzódó viselkedéssel a fiúk körében (Walker, 2005).

Slaughter, Dennis és Pritchard (2002) vizsgálatukban öt különböző tudatelméleti teszten nyújtott teljesítményt vetett össze a gyerekek szociometriai státuszával 4-6 éves gyerekek körében. Az eredményeik szerint az ötévesnél idősebb gyerekek körében szignifikáns összefüggés mutatkozik az összesített tudatelméleti teljesítményük és a társak általi kedveltségük között: a népszerü gyerekek magasabb szinten teljesítenek a tudatelméleti teszteken, mint az elutasított társaik. Másik vizsgálatukban szintén 4-6 éves gyerekeket vizsgáltak, a szociometriai pozíció, a tudatelméleti müködés, a verbális intelligencia, illetve a pedagógus által megítélt proszociális vagy agresszív viselkedés összefüggéseiben. Ebben a vizsgálatban az ötévesnél idősebb gyermekek körében az összesített tudatelméleti teljesítmény volt a legerősebb előrejelzője a társak általi elfogadásnak. Az eredmények alapján a tudatelmélet képességének szerény hatása van a társak általi elfogadottságra ebben az életkorban, ám ez az összefüggés az évek előrehaladtával nő.

\section{A tudatelmélet és a társas hatékonyság kapcsolata iskoláskorban}

James, Astington és Pelletier (2000) longitudinális vizsgálatukban a tudatelméleti képességet a metakognitív nyelvi képességekkel és az iskolai teljesítménnyel összefüggésben vizsgálták, miután kiszürték az általános nyelvi képességek és a családi háttérváltozók tudatelméleti müködésre gyakorolt hatását. A kutatás legfontosabb kérdése az volt, vajon a mentális állapotok tulajdonításának képessége mennyire kapcsolódik össze az iskolai sikerekkel, ez utóbbiba beletartoznak a gyermek akadémiai és társas készségei is. A longitudinális kutatásban két éven keresztül követték a gyerekeket, az iskolába lépésüktől kezdve (a vizsgálat kezdetén a gyerekek átlagéletkora a fiatalabb életkori csoportban 4,4 év, az idősebb életkori csoportban 5,4 év volt). A tudatelmélet mérésére a kutatás első évének elején hamisvélekedés-teszteket vettek fel a gyerekekkel, a második év végén pedig másodrendü hamisvélekedés-teszteket alkalmaztak. A gyermekek társas hatékonyságát a tanárok által kitöltött kérdőívvel mérték, mindkét évben más mérőeszközt alkalmazva. A vizsgálat sajátossága volt, hogy az első év közepén, illetve a második év elején is felvették a kérdőívet a pedagógusokkal, a gyerekek ekkorra már új közösségbe kerültek, más pedagógusok tanították őket (Astington, 2003). 
Az eredmények szerint a gyermekek hamisvélekedés-teszten mért teljesítménye elöre jelzi a kutatás második évének végén mért társas viselkedést. Vizsgálták a kutatók a gyerekek saját tapasztalatait, önbeszámolójuk alapján az iskoláról, a pedagógus-diák kapcsolatról és a kortárskapcsolatokról is. A gyerekek pozitív iskolai tapasztalatai és a másodfokú hamisvélekedés-teszten elért teljesítményük között pozitív, míg a gyerekek negatív tapasztalatai és az első- és másodfokú hamisvélekedés-teszten elért eredményei között negatív kapcsolatot találtak. Továbbá összefüggést mutattak ki a pedagógus által értékelt szociális kompetencia és a gyerekek saját iskolai tapasztalatai között. A pozitív iskolai tapasztalatokkal rendelkező gyerekeket a pedagógusaik is magasabb szociális kompetenciával rendelkezőnek jellemezték, míg a negatív tapasztalatokkal rendelkező gyerekeket kevésbé kompetensnek ítélték meg.

Az eredmények arra utalnak, hogy a hamis vélekedés megértése ugyan szükséges bizonyos szociális viselkedések megértéséhez, azonban nem elégséges a szociális müködéshez (Astington, 2003).

Liddle és Nettle (2006) kutatásukban magasabb szintű tudatelméleti müködés és szociális készségek vizsgálatát tüzték ki célul 10-11 éves gyermekek körében. Magasabb rendü tudatelméleti feladatokat alkalmaztak, illetve a tanárok számára készített kérdőívvel vizsgálták a gyerekek szociális kompetenciáját. A tudatelméleti feladatokban a klasszikus elsőrendü, másodrendü, illetve harmad- és negyedrendü mentális állapottulajdonítás is szerepelt. A gyerekek közül az első- és másodrendü tudatelméleti feladatokat teljesítették a legtöbben, illetve a szociális kompetencia és a tudatelméleti teljesítmény között pozitív összefüggéseket mutattak ki (Liddle és Nettle, 2006).

$\mathrm{Az}$ ismertetett kutatások kritikája elsősorban arra vonatkozik, hogy a hamisvélekedés-tesztek nem elég naturalisztikusak, vagyis nem ragadják meg azt a komplexitást, amit egy valós társas helyzet állít a gyermekek elé. Ennek kapcsán Banerjee és Watling (2005) egy longitudinális projekt keretében a gyerekek tudatelméleti müködését a Faux Pas-teszttel vizsgálták, ami egy komplex, valós szituációkat exponáló történetsorozat, sokkal közelebb áll a valós társas szituációkhoz. A tudatelméleti teljesítményt a szociometriai pozícióval összefüggésben vizsgálták, és kiderült, hogy az elutasított és az ellentmondásos/ambivalens státuszú gyerekek, akik több negatív jelölést kaptak a társaiktól, tudatelméleti teljesítménye alacsonyabb szintü volt a teszttel mérve. Ez az összefüggés az idősebb, 8-9 éves gyerekek almintájában volt jellemző, a fiatalabb, 5-6 éves korosztályban ezt a hatást nem azonosították. Egy későbbi tanulmányukban (Banerjee, Watling és Caputi, 2011) ugyanezen gyerekek kétéves, követéses vizsgálatát mutatták be, ugyancsak a Faux Pas teszttel mért tudatelméleti teljesítményt hasonlították össze a gyerekek szociometriai pozíciójával. Az eredmények arra utalnak, hogy a hétéves kori, csoporton belüli elutasítás bejósolja az alacsonyabb szintü faux pas megértést nyolcéves korban, hasonló hatást figyeltek meg a kilencéves kori elutasítottság és a 10 éves kori faux pas megértés színvonala között. Viszont a kilencéves kori, magasabb szintű faux pas megértés együttjár a 10 éves kori társak általi elfogadottsággal, illetve a 10 éves korban mért alacsonyabb faux pas megértés bejósolja a 11 éves kori elutasítottságot. A szerzők szerint a későbbi kutatások rávilágíthatnak a Faux Pas-teszttel mért teljesítmény és a társak általi elutasítottság közötti mediáló változókra (Banerjee, Watling és Caputi, 2011).

További kutatások is foglalkoznak a társas viselkedés és a tudatelméleti müködés kapcsolatával. Ilyen az iskolai környezetben megfigyelhető zaklatás (bullying) és a tudatelmélet kapcsolatának vizsgálata, hiszen vannak olyan gyerekek, akik a fejlettebb tudatelméleti müködésüket antiszociális célokra használják (Slaughter és Repacholi, 2003). Mivel a mindennapokban gyakori jelenség az iskolai zaklatás, így szükséges tisztázni a bullying mögött rejlö folyamatokat. Az iskolai zaklatás jelenségének, az elkövetők, a provokatív áldozatok, illetve az áldozatok zaklatásban való szerepének jobb megértéséhez is szükséges a tudatelméleti müködés minél részletesebb feltérképezése. 
Vajon tudatelméleti alulmüködés vagy éppen tudatelméleti előny jellemzi a zaklatókat? Nincsenek egyértelmü eredmények, hiszen nehezen kezelhető vagy például magatartászavarral küzdő gyermekek rosszabbul teljesítenek a hamisvélekedés-teszteken, illetve amennyiben teljesítik azt, nincs összhangban a való életben tapasztalható szociális müködéssel. Ennek ellentmond az, hogy a zaklató általában dominánsabb, manipulatív gyermek, ehhez viszont magasabb szintü tudatelméleti müködésre van szüksége (Sutton, 2003). Az ötéves korban mért, alacsonyabb tudatelméleti teljesítmény összefüggésben áll a serdülőkori bullyingban való részvétellel egy longitudinális ikerkutatás eredményei szerint. Azok a serdülők, akik akár áldozatok, akár provokatív áldozatok, akár zaklatók, azok alacsonyabb színvonalú gyermekkori tudatelméleti teljesítménnyel jellemezhetők, azonban a háttérváltozók hatásának is komoly szerepe lehet az iskolai zaklatásban (Sania és mtsai, 2012).

\section{Összegzés}

A tanulmány célja a tudatelméleti müködés tipikus fejlődésének bemutatása óvodáskortól fiatal felnőttkorig, kitérve a fejlődést befolyásoló háttérváltozókra, illetve a társas viselkedéssel való kapcsolatra. A tudatelmélet csecsemőkori és kisgyermekkori fejlődésével számos kutatás foglalkozott, csakúgy, mint az atipikus fejlődésmenet kérdésével (pl. autizmussal kapcsolatos tudatelméleti vizsgálatok). Azonban az óvodás és kisiskolás kort követő vizsgálatok még kevés eredménnyel szolgálnak a szociális kogníció és a tudatelmélet fejlődésének alaposabb megértése céljából. Különösen fontos lehet a tudatelméleti komponensek részletes vizsgálata, fejlődésük nyomon követése. Az affektív és kognitív tudatelméleti komponensek fejlődésének feltérképezése, a hatékony társas viselkedéssel való kapcsolata nem csak az alapkutatás, hanem az alkalmazott területek számára is fontos lenne. Az iskolai sikerességben, illetve az iskolai komplex fejlesztésben elengedhetetlen nemcsak a tantárgyi tudás, a mögöttes gondolkodási képességek, hanem a szociális készségek fejlesztése is. A tudatelmélet és a társas viselkedés közötti kapcsolat nem egyértelmü, a kutatások egy része nem talált, vagy gyenge kapcsolatot talált a két terület között. Fontos azonban hangsúlyozni, hogy a vizsgálatokban alkalmazott tudatelméleti tesztekben általában egy jól körülhatárolt problémával találkozik a gyermek, ugyanakkor a társas világ problémái és konfliktusai nem mindig pontosan körülhatároltak, illetve több személlyel interakcióban folynak. A klasszikus vizsgálóeljárások mellett szükséges olyan kutatásokat végezni, amelyekben realisztikusabb tudatelméleti teszteket alkalmaznak (pl. Banerjee, Watling és Caputi, 2011). A továbbiakban szükséges tisztázni és a későbbi vizsgálatokban szem előtt tartani a vizsgált gyermekek életkorát, a tudatelméleti fejlettség megfelelő módszerekkel való felmérését, továbbá a szociális kompetencia más komponenseivel való kapcsolat kutatását is. Például az iskolai együttmüködés, versengés, vagy éppen a szociálisprobléma-megoldó gondolkodás és a tudatelméleti működés kapcsán végzett vizsgálatok fontos alapjául szolgálhatnak későbbi iskolai fejlesztő programoknak. Akár a szociometriai pozíció, akár a szociális kompetencia egyes összetevői (versengés, együttmüködés, szociálisprobléma-megoldás) és a tudatelmélet közötti kapcsolat részletesebb vizsgálatára további kutatások tervezhetők.

Mindemellett azonban a tudatelméleti működés egészséges fejlődésének megismerése, a családiháttér-változókkal való kapcsolata (pl. SES, testvérek száma) elengedhetetlen nemcsak az iskolai fejlesztéshez, hanem a bullying jelenségének alaposabb megismeréséhez is. A kutatási eredmények fényében hosszú távú cél azonban egy olyan komplex, a tudatelméleti képesség fejlesztését is magában foglaló, magyar viszonyokra kialakított fejlesztőprogram (pl. Lecce és mstai, 2014), ami hatékonyan alkalmazható az iskolai alkalmazkodás sikerességének elősegítésében, illetve akár az iskolai zaklatás jelenségének kezelésében. 


\section{Irodalomjegyzék}

Altgassen, M., Vetter, N. C., Phillips, L. H., Akgün, C. és Kliegel, M. (2014): Theory of mind and switching predict prospective memory performance in adolescents. Journal of Experimental Child Psychology, 127. 163-175. DOI: 10.1016/j. jecp.2014.03.009

Apperly, I. (2011): Mindreaders: The Cognitive Basis of Theory of Mind. Psychology Press. DOI: 10.4324/9780203833926

Astington, J. és Jenkins, J. M. (1999): A longitudinal study of the relation between language and theory-ofmind development. Developmental Psychology, 35. 5. sz. 1311-1320. DOI: 10.1037//00121649.35.5.1311

Astington, J. W. (2003): Sometimes Necessary, Never Sufficient. False-Belief Understanding and Social Competence. In: Repacholi, B. és Slaughter, V. (szerk.): Individual differencies in Theory of Mind. Implications for typical and atypical development. Psychology Press, New York. 14-40. DOI: 10.4324/9780203488508

Banerjee, R. és Watling, D. (2005): Children's understanding of faux pas: Associations with peer relations. Hellenic Journal of Psychology: Special Issue on Theory of Mind, 2. 27-45.

Banerjee, R., Watling, D. és Caputi, M. (2011): Peer Relations and the Understanding of Faux Pas: Longitudinal Evidence for Bidirectional Associations. Child Development, 82. 6. sz. 1887-1905. DOI: 10.1111/j.1467-8624.2011.01669.x

Baron-Cohen, S. (1995): Mindblindness: an essay on autism and theory of mind. MIT Press/Bradford Books.

Baron-Cohen, S. (2001): Theory of mind in normal development and autism. Prisme, 34. 174-183.

Baron-Cohen, S., Jolliffe, T., Mortimore, C. és Robertson, M. (1997): Another advanced test of theory of mind: Evidence from very high functioning adults with autism or Asperger Syndrome. Journal of Child Psychology and Psychiatry, 38. 813-822. DOI: 10.1111/j.1469-7610.1997.tb01599.x

Baron-Cohen, S., Leslie, A. M. és Frith, U. (1985): Does the autistic children have a ,theory of mind"? Cognition, 21. 37-46. DOI: 10.1016/00100277(85)90022-8

Baron-Cohen, S., O’Riordan, M., Stone, V., Jones, R. és Plaisted, K. (1999): A new test of social sensitivity: Detection of faux pas in normal children and children with Asperger syndrome. Journal of Autism and Developmental Disorders, 29. 407-418.

Baron-Cohen, S., Wheelwright, S., Hill, J., Raste, Y. és Plumb, I. (2001): The Reading the Mind in the Eyes Test revised version: A study with normal adults, and adult with Asperger syndrome or high- functioning autism. Journal of Child Psychology and Psychiatry, 42. 2. sz. 241-251. DOI: $10.1111 / 1469$ 7610.00715

Bíró Szilvia (2002): A naiv pszichológiai „értelmezés" kezdetei: a racionális cselekvés elvének kisérleti vizsgálata csecsemökorban. Osiris Kiadó, Budapest.

Blakemore, S-J. (2008): Development of the social brain during adolescence. The Quarterly Journal of Experimental Psychology, 61. 1. sz. 40-49. DOI: 10.1080/17470210701508715

Blakemore, S-J. (2012): Development of the social brain in adolescence. Journal of the Royal Society of Medicine, 105. 111-116. DOI: 10.1258/ jrsm.2011.110221

Bodden, M. E., Mollenhauer, B., Trenkwalder, C., Cabanel, N., Eggert, K. M., Unger, M. M., Oertel, W. H., Kessler, J., Dodel, R. és Kalbe, E. (2010): Affective and cognitive theory of mind in patiens with Parkinson's disease. Parkinsonism and Related Disorders, 16. 466-470. DOI: 10.1016/j. parkreldis.2010.04.014

Brüne, M. és Brüne-Cohrs, U. (2006): Theory of mind - evolution, ontogeny, brain mechanisms and psychopathology. Neuroscience and Biobehavioral Reviews, 30. 437-455. DOI: $10.1016 / \mathrm{j}$. neubiorev.2005.08.001

Carlson, S. M. és Moses, L. J. (2001): Individual differences in inhibitory control and children's theory of mind. Child Development, 72. 1032-1053. DOI: 10.1111/1467-8624.00333

Carlson, S. M., Moses, L. J. és Breton, C. (2005) How specific is the relation between executive function and theory of mind? Contributions of inhibitory control and working memory. Infant and Child Development, 11. 2. sz. 73-92. DOI: 10.1002/ icd. 298

Cutting, A. L. és Dunn, J. (1999): Theory of Mind, Emotion Understanding, Language, and Family Background: Individual Differences and Interrelations. Child Development, 70. 4. sz. 853-865. DOI: $10.1111 / 1467-8624.00061$

Csibra Gergely és Gergely György (2002): A naiv tudatelmélet az evolúciós lélektan szempontjából. Magyar Tudomány, 47. 1. sz. 56-63.

Csibra Gergely és Gergely György (2005): Teleologikus gondolkodás csecsemőkorban. Az egyévesek naiv racionális cselekvéselmélete. Magyar Tudomány, 50. 11. sz. 1347-1354.

Csibra, G., Bíró, S., Koós, O. és Gergely, G. (2003): One-year-old infants use teleological representations of actions productively. Cognitive Science, 27. 111133. DOI: $10.1207 / \mathrm{s} 15516709 \operatorname{cog} 2701 \_4$

Dumontheil, I., Apperly, I. A. és Blakemore, S.J. (2010): Online use of mental state inferences 
continues to develop in late adolescence. Developmental Science, 13. 2. sz. 331-338. DOI: 10.1111/j.1467-7687.2009.00888.x

Dunn, J., Brown, J., Slomkowski, C., Tesla, C. és Youngblade, L. (1991): Young children's understanding of other people's feelings and beliefs: Individual differences and their antecedents. Child Development, 62. 1352-1366. DOI: 10.1111/j.1467-8624.1991.tb01610.x

Dunn, J., Cutting, A. L. és Demetriou, H. (2000): Moral sensibility, understanding others, and children's friendship interactions in the preschool period. British Journal of Developmental Psychology, 18. 159177. DOI: $10.1348 / 026151000165625$

Egyed Katalin és Király Ildikó (2008): Mások viselkedésének megértése és az éntudatosság. In: Csépe Valéria, Győri Miklós és Ragó Anett (szerk.): Általános pszichológia 3. Nyelv, tudat, gondolkodás. Osiris, Budapest. 336-356.

Gál Zita, Egyed Katalin, Pászthy Bea és Németh Dezső (2011): Tudatelméleti deficit anorexia nervosában. Psychiatria Hungarica, 26. 1. sz. 12-25.

Gergely György, Egyed Katalin és Király Ildikó (2007): A természetes pedagógiáról. Magyar Pszichológiai Szemle, 62. 1. sz. 107-125. DOI: 10.1556/ mpszle.62.2007.1.5

Gunther Moor, B., Op de Maks, Z. A., Güroglu, B., Rombouts, S. A. R. B., Van der Molen, M. W. és Crone, E. A. (2012): Neurodevelopmental changes of reading the mind in the eyes. Social Cognitive and Affective Neuroscience (SCAN), 7. 44-52. DOI: $10.1093 /$ scan/nsr020

Happé, F. (1995): The role of age and verbal ability in the ToM performance of subjects with autism. Child Development, 66. 843-855. DOI: 10.1111/j.1467-8624.1995.tb00909.x

Hogrefe, G. J., Wimmer, H. és Perner, J. (1986): Ignorance versus false belief: a developmental lag in attribution of epistemic states. Child Development, 57. 567-582. DOI: 10.1111/j.1467-8624.1986. tb00228.x

Ivády Rozália Eszter, Takács Boglárka és Pléh Csaba (2007): Tudatelmélet és idegen nyelvelsajátítás valódi kapcsolat vagy városi legenda? In: Kampis György és Mund Katalin (szerk.): Tudat és elme. Typotex, Budapest. 59-74.

James, T., Astington, J. W. és Pelletier, J. (2000): Children's per-ception of school: Relations to theory of mind, school performance and family life. Paper presented at the Development 2000, Conference of Developmental Section of Canadian Psychological Association, Waterloo, Canada.

Jenkins, J. M. és Astington, J. W. (1996): Cognitive factors and family structure associated with theory of mind development in young children. Developmental Psychology, 32. 70-78. DOI: 10.1037//00121649.32.1.70
Kalbe, E., Schlegel, M., Sack, A. T., Nowak, D. A., Dafotakis, M., Bangard, C., Brand, M., ShamayTsoory, S., Onur, O. A. és Kessler, J. (2010): Dissociating cognitive from affective theory of mind: a TMS study. Cortex, 46. 769-780. DOI: 10.1016/j. cortex.2009.07.010

Kiss Szabolcs (2005): Elmeolvasás. Új Mandátum Kiadó, Budapest.

Kovács, Á. M., Téglás, E. és Endress, A. D. (2010): The social sense: susceptibility to others' beliefs in human infants and adults. Science, 330. 1830-1834. DOI: 10.1126/science.1190792

Lalonde, C. E. és Chandler, M. J. (1995): False belief understanding goes to school: On the social-emotional consequences of coming early or late to a first theory of mind. Cognition and Emotion, 9. 167-185. DOI: 10.1080/02699939508409007

Lecce, S., Bianco, F. Devine, R. T., Hughes, C. és Banerjee, R. (2014): Promoting theory of mind during middle childhood: A training program. Journal of Experimental Child Psychology, 126. 52-67. DOI: $10.1016 /$ j.jecp.2014.03.002

Lewis, C., Freedman, N. H., Kryiakidou, C., Maridaki-Kassotaki, K. és Berridge, D. M. (1996): Social influences on false belief access: Specific sibling influences or general apprenticeship. Child Development, 67. 2930-2947. DOI: 10.1111/j.1467-8624.1996.tb01896.x

Liddle, B. és Nettle, D. (2006): Higher-order theory of mind and social competence in school-age children. Journal of Cultural and Evolutionary Psychology, 4 231-246. DOI: 10.1556/jcep.4.2006.3-4.3

McAlister, A. és Peterson, C. C. (2007): A longitudinal study of child siblings and theory of mind development. Cognitive Development, 22. 258-270. DOI: 10.1016/j.cogdev.2006.10.009

Newton, P., Reddy, V. és Bull, R. (2000): Children's everyday deception and performance on false-belief tasks. British Journal of Developmental Psychology, 18. 297-317. DOI: 10.1348/026151000165706

Pears, K. C. és Moses, L. J. (2003): Demographics, parenting and theory of mind in preschool children. Social Development, 12. 1. sz. 1-20. DOI: 10.1111/1467-9507.00219

Perner, J. és Lang, B. (1999): Development of theory of mind and executive control. Trends in Cognitive Sciences, 3. 9. sz. 337-344. DOI: 10.1016/s13646613(99)01362-5

Perner, J., Ruffman, T. és Leekam, S. (1994): Theory of Mind is contagious: You Catch it from your sibs. Child Development, 65. 1228-38. DOI: 10.1111/j.1467-8624.1994.tb00814.x

Peterson, C. és Slaughter, V. (2003): Opening windows into the mind: mothers' preferences for mental state explanations and children's theory of 
Gál Zita: A tudatelmélet életkori változásainak és szerepének áttekintése óvodáskortól fiatal felnőttkorig

mind. Cognitive Development, 18. 399-429. DOI: 10.1016/s0885-2014(03)00041-8

Poletti, M., Enrici, I., Bonuccelli, U. és Adenzato, M. (2011): Theory of mind in Parkinson's disease. Behavioural Brain Research, 36. 2147-2164. DOI: 10.1016/j.bbr.2011.01.010

Premack, D. és Woodruff, G. (1978): Does the chimpanzee have a ,theory of mind"? Behavioral and Brain Sciences, 4. 515-526. DOI: 10.1017/ s0140525x00076512

Ruffman, T., Slade, L., Devitt, K és Crowe, E. (2006): What mothers say and what they do: The relation between parenting, theory of mind, language and conflict/cooperation. British Journal of Development Psychology: Special Issue, 24. 105-124. DOI: $10.1348 / 026151005 \times 82848$

Ruffman, T., Slade, L. és Crowe, E. (2002): The relation between children's and mothers' mental state language and theory-of-mind understanding. Child Development, 73. 734-751. DOI: 10.1111/14678624.00435

Sania, S., Jaffee, S. R., Bowes, L., Ouellett-Morin, I., Andreou, P., Happé, F., Moffitt, T. E. és Arseneault, L. (2012): A prospective longitudinal study of children's theory of mind and adolescent involvement in bullying. Journal of Child Psychology and Psychiatry, 53. 3. sz. 254-261. DOI: 10.1111/j.1469-7610.2011.02488.x

Sebastian, C. L., Fontaine, N. M. G., Bird, G., Blakemore, S-J., De Brito, S. A., McCrory, E. J. P. és Viding, E. (2012): Neural processing associated with cognitive and affective Theory of Mind in adolescents and adults. Social Cognitive and Affective Neuroscience (SCAN), 7. 1. sz. 53-63. DOI: 10.1093/ scan/nsr023

Shamay-Tsoory, S. G., Shur, S., Barcai-Goodman, L., Medlovich, S., Harari, H. és Levkovitz, Y. (2007): Dissociation of cognitive from affective components of theory of mind in schizophrenia. Psychiatry Research, 149. 11-23. DOI: 10.1016/j. psychres.2005.10.018

Shamay-Tsoory, S. G., Harari, H., Aharon-Peretz, J. és Levkovitz, Y. (2010): The role of the orbitofrontal cortex in affective theory of mind deficits in criminal offenders with psychopathic tendencies. Cortex, 46. 5. sz. 668-677. DOI: 10.1016/j.cortex.2009.04.008

Slade, L. és Ruffman, T. (2005): How language does (and does not) relate to theory of mind: A longitudinal study of syntax, semantics, working memory and false belief. British Journal of Developmental
Psychology, 23. 117-141. DOI: 10.1348/026151004x21332

Slaughter, V. és Repacholi, B. (2003): Introduction: Individual Differences in Theory of Mind. What Are We Investigating? In: Repacholi, B. és Slaughter, V. (szerk.): Individual differencies in Theory of Mind. Implications for typical and atypical development. Psychology Press, New York. 1-14. DOI: 10.4324/9780203488508

Slaughter, V., Dennis, M. J. és Pritchard, M. (2002): Theory of mind and peer acceptance in preschool children. British Journalof Developmental Psychology, 20. 545-564. DOI: 10.1348/026151002760390945

Stone, V., Baron-Cohen, S. és Knight, R. T. (1998): Frontal Lobe Contributions to Theory of Mind. Journal of Cognitive Neuroscience, 5. 640-656. DOI: 10.1162/089892998562942

Suddendorf, T. és Fletcher-Flinn, C. M. (1999): Children's divergent thinking improves when they understand false beliefs. Creativity Research Journal, 12. 115-128. DOI: $10.1207 / \mathrm{s} 15326934$ crj1202_4

Sutton, J. (2003): ToM Goes to School. Social Cognition and Social Values in Bullying. In: Repacholi, B. és Slaughter, V. (szerk.): Individual differencies in Theory of Mind. Implications for typical and atypical development. Psychology Press, New York. 99-122. DOI: 10.4324/9780203488508

Vetter, N. C., Altgassen, M., Phillips, S., Mahy, C. E. V. és Kliegel, M. (2013): Development of Affective Theory of Mind Across Adolescence: Disentangling the Role of Executive Functions. Developmental Neuropsychology, 38. 2. sz. 114-125. DOI: 10.1080/87565641.2012.733786

Walker, S. (2005): Gender Differences in the Relationship Between Young Children's Peer-Related Social Competence and Individual Differences in Theory of Mind. The Journal of Genetic Psychology, 116. 3. sz. 297-312. DOI: $10.3200 /$ gntp.166.3.297312

Watson, A. C., Nixon, C. L., Wilson, A. és Capage, L. (1999): Social interacton skills and Theory of Mind in young children. Developmental Psychology, 35. 2. sz. 38 $\overline{8} 6--391$. DOI: 10.1037//0012-1649.35.2.386

Wimmer, H. és Perner, J. (1983): Beliefs about beliefs: representation and contraining function of wrong beliefs in young children's understanding of deception. Cognition, 13. 103-128. DOI: 10.1016/0010-0277(83)90004-5 